\title{
Correction to: Indian Cotton Textiles in West Africa
}

\section{Correction to:}

K. Kobayashi, Indian Cotton Textiles in West Africa, Cambridge Imperial and Post-Colonial Studies Series, https://doi.org/10.1007/978-3-030-18675-3

In the original version of the book, the following belated corrections have been made: In chapter 2, the source for Table 2.1 has been added. In chapter 3, sources for Image 3.2 and Figure 3.2 have been updated.

The original version of this book was revised: Belated corrections have been incorporated. The corrections to this book can be found at https://doi.org/10.1007/978-3-030-18675-3, https://doi.org/10.1007/978-3-030-18675-3_2, https://doi.org/10.1007/978-3-030-18675-3_3

(C) The Author(s) 2019

K. Kobayashi, Indian Cotton Textiles in West Africa, Cambridge Imperial and Post-Colonial Studies Series, https://doi.org/10.1007/978-3-030-18675-3_7 